until now, the larger part of the work of Columbia's physicists and of numerous members of other departments has been devoted to the problems of nuclear fission and the release of atomic energy".

The "Manhattan Project", so-called, was centred at Columbia during 1939-45, utilizing much of the scientific space of the University and, with its scientific staff of 250 and 1,200 others, overflowing into other buildings in the neighbourhood. The work with the uranium-graphite pile was shifted to Chicago in 1942, and the chief effort at Columbia was devoted to the gaseous diffusion method of separating uranium-235.

The chief contributions of Columbia University, however, have been in fields other than science, which was a relatively late development. Great lawyers, judges, and legal scholars have issued in continuous line throughout its history-the two Roosevelt presidents coming from its law school, as also three chief justices and many associate justices ; statesmen-from Alexander Hamilton, John Jay, DeWitt Clinton (the governor of New York who built the Erie Canal) - to the present governor. It was from Columbia that F. D. Roosevelt drew his 'brain trust' of 1932; his rival for the Democratic nomination in that year is said to have poached on Roosevelt's preserves, and the two candidates gave forth with one speech written impartially for both by the same Columbia 'ghost'. The Faculty of Political Science has had a long and honourable history, but it must be told by one who knows. In philosophy one thinks of John Dewey, who spent fifty active, even turbulent, years at the University; in anthropology, of Franz Boas, who between 1893 and 1940 was responsible not only for the creation of a school of linguistics but also put his stamp on the whole of American anthropology, both social and physical.

But it would be idle for one who is not a historian, nor capable of judgment outside of the restricted field of his own experience in science, to choose more persons or events for emphasis from an array extending over two hundred years.

I write from Rome, a distance of half the globe away, and after nearly a year's absence from that University. In the United States it seems like a European university, in the independence of its faculties and schools and departments, its avoidance of prescription or undue interference with the lives of its students and professors, the absence of indoctrination, conformalization, 'college spirit'. Looked at from Europe, however, one readily perceives an American look-a fluidity and responsiveness to the times that is less clearly seen in the older European foundations that depend on the State. In the past this fluidity was made possible by the University's freedom to dispose of its own income from endowment as it saw fit. With the new increase in cost and the decrease in income from investments, this freedom is now restricted. New things can still be done in such an American university, in part because resources from the great philanthropic foundations can be placed quickly at the disposal of persons with new ideas. Fortunately, this is now not restricted to American universities but is increasingly shared by learned institutions elsewhere. This, and the increasing participation of government and of industry in support of research through contractual arrangements, will surely profoundly affect the future of Columbia as of other universities.

\section{AGRICULTURAL EDUCATION IN GREAT BRITAIN}

GOR any adequate appreciation of the recent Report of the Working Party on Agricultural Education* some knowledge of the changes that have taken place during the past fifteen years is essential. Prior to the Second World War, agricultural education and advice to those engaged in any branch of the agricultural industry constituted $a$ single service maintained by local government bodies-usually county councils-but financed mainly by the Ministry of Agriculture, not the Ministry of Education. A fraction of the cost was borne by the rates. The committee of the county council controlling the service was, as a rule, the Agriculture Committee, which often delegated this particular section of its work to an Agricultural Education Sub-Committee. In the dozen or so counties where an agricultural institute existed, this was normally controlled by the same body or a further sub-committee.

The chief officer of the county council responsible for the service was the agricultural organizer of agricultural education and, with rare exceptions, every county council had such an officer. His status in the hierarchy of county officials was high, often with the right of direct access to the clerk of the county council. Owing to the comparatively small number of agricultural organizers, it was also easy for them to have, unofficially, personal contacts with senior officials of the Ministry of Agriculture in London, which also maintained a small inspectorate. The whole set-up was a loose one-typically British -which worked brilliantly or dismally, depending on the county personnel-the officials appointed and the members of the Agricultural Education Subcommittee.

In some counties, a very fine system of agricultural education had been built up, with day and evening classes in various centres covering practically all the branches of agriculture and horticulture found within the county. The organizer, in addition, had his tasks of giving advice to farmers and other growers, visiting farms when necessary to take samples of soil, milk, feeding stuffs, etc. Also, he conducted demonstrations and experiments of various kinds on commercial farms, for example, on the manuring of grass or other crops, the feeding of livestock, comparison of varieties and the use of weed-killers.

A loose link-up between counties was provided by the provincial centre, situated at a university or agricultural college, as, for example, at the School of Agriculture, Cambridge, for the eastern counties. At the provincial centre there were specialists in chemistry, entomology, etc., on whose services the county organizer could call for the solution of problems which he could not solve himself. Quarterly meetings of the organizers and one or more members of their staffs, held at the provincial centre, provided occasions for the discussion of common problems, the drafting of co-operative experiments and numerous other matters. On the whole, the pre-War system of agricultural education in the counties was a happy one which, moreover, was capable of rapid development by taking the forward counties as a model and spurring on any laggard to approach the same level of achievement.

* Ministry of Agriculture and Fisheries. Report of the Working Party on Agricultural Education. Pp. 20 . (London: H.M. Stationery
Office, 1953.) 9d. net. 
The proof of the system came with the Second World War. The agricultural officers of the local authorities were seconded as officials and advisers to the War Agricultural Committees, and it is not extravagant to claim that the tremendous advance made by British agriculture during the War was, in a large measure, due to the advice and help rendered to these committees by the local agricultural staffs.

In one sense they were too successful, for so impressed was the Ministry of Agriculture with their value as advisers-temporarily, through war-time regulations, under centralized control-that it decided, before the War ended, to set up a National Agricultural Advisory Service distinct from the County Agricultural Education Service. What had hitherto been one living-usually lively-organism was to be cut in two. This was done by the Agriculture (Miscellaneous Provisions) Act of 1944. It is doubtful whether any such Act could have been put on the statute book except in war-time, when the energies of those mainly concerned were concentrated on winning the battle for food production.

This new advisory service was planned to be set up, almost in toto, at a definite date, October 1, 1946, as a branch of the Civil Service with centralized control. Attractive salary scales were offered and those already engaged in agricultural education before the War were given the right of application for transfer. The alternative was to remain with the local authority with no definite salary scales and with very hazy prospects for the future.

These county staffs provided almost the only source of recruitment for the new advisory service; inevitably it practically denuded the counties of most of their experienced personnel and was an extremely serious blow for agricultural education. This function was now transferred to the Ministry of Education, which had no experience in this field. In the future, 'advice' was somehow or other to be differentiated from 'education'. Further, instead of agricultural education being an important activity of the Ministry of Agriculture, it became a very minor sector of the vast front of the Ministry of Education.

It is not an exaggeration to say that most of those connected with agricultural education-whether or not they transferred to the advisory service-deeply deplored the new system. The late Prof. N. M. Comber, when president of the Agricultural Section of the British Association in 1943, admirably expressed this view in the following words : "Those now engaged in the advisory service have no official colleagueship with those who teach agricultural students in Universities and Colleges, and the teachers have no longer their foretime association with all that is going on in the farming of today. These teachers are, therefore, deprived of what has been the main source of their life-blood as teachers, and the suicidal character of the whole development can be seen by anyone who gives thought about the training of those to be appointed to the Advisory Service staff in the next generation or so. This separation of teaching and advisory work is, in my view, a major tragedy in the history of agricultural education".

It is not surprising, therefore, that, in November 1952 , six years after the formation of the National Agricultural Advisory Service, the Minister of Agriculture and Fisheries set up a 'working party' "To review the relations between the agricultural education service of Local Authorities and the National Agricultural Advisory Service, and to make proposals for their more effective co-operation; to examine the need for an inspectorate of agricultures education; and to consider the future of the Joint Advisory Committee on Agricultural Education". Unfortunately, these terms of reference excluded from its inquiry "major structural changes in responsibility for either education or advice on agricultural subjects". The setting up of the "working party' disclosed the recognition of the existence of $a$ 'dis-ease', but the 'working party' was strictly enjoined not to deal with the real cause of this disease, but merely to suggest measures for its alleviation.

Within such restricted terms of reference the working party in its report published in October last has made a number of minor, but useful, suggestions. Officers of the advisory and education service within each county are advised to meet together at least twice a year in order to organize better team-work and fuller collaboration in each other's activities. Similarly, the authorities responsible for the two sections of work are advised to have overlapping membership. A limited amount of secondment between the services is proposed in counties where staffs are large enough for it to be done. A small inspectorate of persons well qualified in agriculture or horticulture (but not members of the National Agricultural Advisory Service) is suggested. But the finding of greatest importance to the teaching side is that "suitably qualified L.F.A. staff are welcome to advise old students who are commercial producers, nor should they be debarred from advising other commercial producers if asked . . .". The final recommendation is that the Joint Advisory Committee on Agricultural Education, better known as the Loveday Committee, should lapse but be reconstituted when necessary for specific inquiries.

These results of a year's work by the twelve members of the Carrington working party are not very impressive; but in view of the terms of reference, it is difficult to think that the working party could have done better.

H. W. Gardner

\section{THE WORKERS' EDUCATIONAL ASSOCIATION}

$T$

'HE Workers' Educational Association has recently produced two publications which indicate the way in which Great Britain's most prominent voluntary organization in adult education is adapting itself to meet the challenge of new times and new men. The first is a review of the Association's activ. ities since the end of the Second World War, and the second the report of a working party set up to inquire into Trade Union education*.

Looking back to 1920 , the review shows how the Association has been tested in two world wars and emerged from both strengthened and revitalized. In 1913-14, there were 179 branches; 11,430 individual members; and there were 145 classes with 3,343 students. In $1919-20$ there were 277 branches ; 20,703 individual members ; and there were 557 classes with 12,438 students. In 1938-39 there were 635 branches ; 28,652 individual members; and there were * Trade Union Education : a Report from a Working Party set up by the Workers' Educational Association. Pp. 120. 4s. 6d. The Workers' Educational Association. A Review 1946-1952. Pp. 84.
(London : 'Workers' Educational Association, 1953 and 1954.) 